\title{
KOVÁCS TERÉZ: VIDÉKFEJLESZTÉSI POLITIKA
}

\author{
(Dialóg Campus Kiadó, Budapest-Pécs, 2003, 248 o.)
}

\section{PÓLA PÉTER}

A rurális térségekkel kapcsolatos kutatásoknak több tényező kủlönös aktualitást ad. A társadalmi-gazdasági átalakulás a vidék problémáit igen élesen felszínre hozta. Az agrárgazdaság súlyának relatív csökkenésével a rurális térségek sok esetben nehéz helyzetbe kerültek az Európai Unió tagállamaiban és hazánkban egyaránt. Magyarország európai integrációja küszöbén pedig gyakran hallani a magyar agrárgazdaságért és a magyar vidékért aggódó hangokat, melyeket az elkerülhetetlen globalizáció tovább fokoz. A globalizáció viszont együtt jár a lokalizációval, ami a vidékfejlesztést szintén felértékeli, hiszen szuikség van ésszerü, szakmailag is megalapozott vidékfejlesztésre, ha sikeresen akarunk megfelelni a globalizáció kihívásaira. Mindezek tükrében érthető, hogy a vidékfejlesztés miért áll viták kereszttuizében, s talán az is, miért vált kicsit a politika játékszerévé. Annak ellenére, hogy vidékfejlesztésről rengeteget hallani manapság, igazán kevés olyan munka áll a téma iránt érdeklődők rendelkezésére, amely szakmai alapossággal, ugyanakkor tömören és jól érthetően ad képet a vidékfejlesztés elméleti és gyakorlati kérdéseiröl. Kovács Teréz Vidékfejlesztési politika címü könyve ilyen munka.

A könyv két részbỏl áll: az első rész a vidékfejlesztés elméleti, koncepcionális kérdéseit taglalja, a második a vidékfejlesztést érintő politikákról ad átfogó képet úgy az Európai Unióban, mint a csatlakozás előtt álló államokban, különös figyelemmel a hazai helyzetre. A könyv melléklete a vidékfejlesztési programozás módszertanába vezeti be az olvasót, mely elsősorban a vidékfejlesztési programokat készítők számára nyújt hasznos információt, segítséget.

„A vidékfejlesztés alapjaì" címet viselö rész ismerteti az olvasóval a vidékfejlesztés legfontosabb fogalmait, kezdve a vidék fogalmának meghatározásával, mely témában éppen a Szerző kezdeményezett tartalmas vitát a Gazdálkodás c. folyóirat hasábjain. Megismerheti az olvasó a vidék definiálásának nehézségeit, s helyenként a vidék szinonimájaként is használt falusi, rurális jelzók árnyalatbeli különbségeit, azok eredetét. A vidék, vidéki térség meghatározás persze nem öncélú, nagyon is húsba vágó kérdés, gondoljunk csak arra, hogy sok esetben a tảmogatások feltétele, hogy az adott térség vidéki jellegúnek minösüljön.

A rurális térségek meghatározásakor megismerhetjük az EU és az OECD mutatóit. Magyarországon a besorolás kapcsán három nyitott kérdést említ a könyv: Az ország mekkora területe rurális térség; körzeti szintü vagy településsoros lehatároláshoz célszerü kötódnie a meghatározásnak; milyen léptékủ tér tekinthető a vidékfejlesztés optimális terének, leghangsúlyosabban pedig az, hogy melyek a támogatandó 
vidéki területek? E kérdések kapcsán megismerhető néhány fontosabb lehatárolási módszer, javaslat.

A könyv egy igen érdekes és nem kevésbé tartalmas fejezete a vidékkutatással foglalkozik. „Napjainkban nagy kihívás a vidékkutatások összekapcsolása a vidékfejlesztéssel. Miután a kutatás és fejlesztés összekapcsolódik, a kutatásnak egyre nagyobb szerepe van a fejlesztésben." - írja a Szerző a 31. oldalon. Egyesek szerint pedig a vidékfejlesztés új tudományos diszciplína (Laczkó I., Kovács T.) vagy legalábbis önálló szakterület (Kulcsár L.). E fejezetből ismerheti meg az olvasó annak, az Európában lezajlott paradigmaváltásnak a szakaszait, melynek során a falukutatás vidékkutatássá alakult át, $\mathrm{s}$ annak interdiszciplináris jellege felerősödött. A magyarországi vidékkutatás kapcsán szintén a falukutatásig nyúl vissza a Szerző. A falukutató szociológusoktól a földrajztudományon át az agrártudomány képviselőinek legfontosabb véleményeit is bemutatja ez a fejezet.

A második világháború után lezajlott, a vidék fejlődése szempontjából meghatározó térbeli-települési fejlődés ismertetése és értékelése három jellegzetes időszakaszban kerül bemutatásra: az extenzív fejlődés időszakában; a hetvenes évektöl a rendszerváltásig terjedő időszakban; és a posztszocializmus korában. Lényegre törően ismerteti az urbanizáció, s ezzel párhuzamosan a ruralizáció folyamatait, szakaszait. A hazai urbanizációs folyamatok elemzése során kitér az Európához viszonyított megkésett fejlődés értelmezésére, ismertetve Szelényi és Enyedi ez irányú vélekedéseit. Kovács Teréz kitér a ruralitás három dimenziójának (foglalkozási, szociokulturális és ökológiai) ismertetésére, amit azzal a megállapítással öszszegez, miszerint ,az ezredfordulón Nyugat-Európa az ökológiai, Közép-KeletEurópának egyes térségei pedig a foglalkozási ruralizáció felé tartanak." (44. o.) Ez pedig, mint a Szerzö is - a téma kiváló külföldi ismerőinek elemzése alapján megjegyzi, egymástól két eltérő forgatókönyv megvalósítását jelenti. A fent említett, három különbözö korszak társadalmi folyamatainak, szociológiai jellegzetességeinek bemutatása a vidék, a vidéki társadalom problémáinak megértését segíti. A fejezet bemutatja a modernizáció, a posztfordizmus hazai leképezödését, a szocialista rendszer vidékre gyakorolt hatását. A rendszerváltást követően a kelet-középeurópai térség sajátosságaiból is eredő modernizációs problémák újabb elméletek születését eredményezik: Zapf „új” modernizációs elméletét és Köles hiányok piramisa elméletét mutatja be a Szerző, s végül ismerteti a településszerkezetben megfigyelhetö legújabb jelenségek szociológiai jellegzetességeit.

Mindezek a változások erős hatást gyakoroltak a rurális térszerkezetre is, melyek a Szerző szerint alapvetően az alábbiak szerint differenciálódnak:

- dinamikusan fejlödö rurális térségek

- elmaradott rurális térségek

- elnéptelenedő rurális térségek.

A vidék szociológiájának történeti áttekintését követően a vidékfejlesztési politika legfontosabb kérdéseire ad választ a könyv. A fenntartható fejlődés, a vidékfejlesztés meghatározása mellett a vidékfejlesztés agrárgazdasághoz és területfejlesztéshez való viszonyával kapcsolatban számos vélemény mellett fejti ki saját álláspontját a 
Szerzö, aki bemutatja a vidékpolitika kapcsolódásait az ágazati politikákhoz és a regionális politikához. Szól a vidékpolitika két modelljérỏl: a városiak érdekében, illetve a falusiak érdekében folytatott vidékpolitikáról.

A könyv II. része tárgyalja részletesen az Európai Unióban, annak tagországaiban, valamint a 2004-ben csatlakozó államokban a vidékfejlesztést érintỏ politikákat, nem hagyva figyelmen kívül az Európa Tanács vidékfejlesztés terén kifejtett tevékenységét. Így szó esik a az EU intézményi és döntéshozatali rendszeréről éppúgy, mint az Európa Tanácsról, s megismerhetjük a Corki nyilatkozat mellett a Rurális Térségek Európai Chartájának alapelveit.

A vidékfejlesztési politika az EU gyakorlatában is erỏsen kapcsolódik az agrárpolitikához és a regionális politikához egyaránt, így az EU közös agrárpolitikájának és regionális politikájának részletes tárgyalása nyilván nem kerülhető meg. A CAP bemutatásán túl megismerhetjük az EU agrárgazdaságát, s nem utolsó sorban megtudhatjuk azt is, milyen okokra vezethető vissza az Unió mezögazdaságának magas támogatottsága. Ezt követően pedig a Szerzỏ összehasonlítja az EU és Magyarország mezőgazdaságát. A közös agrárpolitikát több ponton érhette és érte is kritika, ami a CAP reformjaihoz vezetett. Ezeknek a reformoknak a hátterét, kiváltó okait is megismerheti az olvasó ebből a fejezetből, kezdve a GATT/WTO-forduló hatásaival, folytatva az agrár-környezetvédelem szerepének növekedésével, s végül a Szerző a reformok eredményei mellett nem szủkölködik annak hiányosságainak felvetésekor. Mindezek után megismerhetjük a többfunkciós mezőgazdaságot elötérbe helyezö európai agrármodellt, melynek keretei között a Közös Agrárpolitika helyett egyre gyakrabban a Közös Agrár- és Vidékfejlesztési Politikát említik.

A regionális politika ismertetése, fejlődésének rövid bemutatása után részletesen vizsgálja a kilencvenes évek strukturális politikáját, a regionális fejlesztés irányelveit az Agenda 2000 címú dokumentumot követő 2000-2006 közötti tervezési időszakban is, bemutatva a regionális politikában végbement reformokat, külön hangsúlyozva a vidékfejlesztési támogatások terén történt változásokat. Utóbbiakat illetỏen kitér a vidékfejlesztési intézkedések finanszírozási hátterére, szerkezetére, valamint a vidékfejlesztést szolgáló közösségi kezdeményezés, a LEADERprogram fejlödésére, szervezeti és müködési rendszerére. Az EU vidékfejlesztési gyakorlatának alapos ismertetése után tér rá Kovács Teréz a rendszerváltást követő hazai területfejlesztés és a regionalizáció elemzésére, melynek kapcsán sor kerül a területfejlesztés négyszintủ intézmény- és eszközrendszerének bemutatására.

A könyv II. része külön fejezetet szentel Közép-Kelet-Európa vidékfejlesztési politikájának bemutatására. Ebben a térség legfontosabb gazdasági mutatói mellett az érintett országok mezőgazdaságáról kapunk képet, majd a három elöcsatlakozási alap, a PHARE, az ISPA és a SAPARD müködését és tapasztalatait mutatja be a Szerző. A mezőgazdasági és vidékfejlesztési támogatásokat nyújtó SAPARDprogramról igen átfogó értékelést kapunk, melyben a magyarországi tapasztalatok részletes elemzése is helyet kap.

Megismerheti az olvasó a Nemzeti Fejlesztési Terv mezőgazdaságot és vidékfejlesztést érintő operatív programját (AVOP), $\mathrm{s}$ az európai csatlakozás legfontosabb 
kérdéseit. A 2002 januárjában kelt „Bővítés és mezőgazdaság: az új tagállamok sikeres integrációja a közős agrárpolitikába" címet viselö dokumentum értékelését követöen azt vizsgálja, hogy a magyar tárgyalások milyen eredményekre vezettek a termelői bázis, a kvóták, a földkérdés, a közvetlen kifizetések stb. kérdéskörében.

Kovács Teréz két vidékfejlesztési forgatókönyvet ismertet. Az első, a mezőgazdasághoz kapcsolódó forgatókönyvnél az ÁMÖ alapján az üzemi szerkezet és földhasználat vizsgálatából levont következtetései alapján három típust különböztet meg: a nagyüzemet, a családi gazdaságot és a megélhetést segitô gazdaságot, valamint hangsúlyozza, hogy hazánkban egy szociális mezőgazdaság is létezik, amely a Szerző szerint a szociális földprogramban és a termelői közösségek támogatásában nyilvánul meg. A mezőgazdaságon kívüli vidékfejlesztési forgatókönyv a rurális térségek foglalkoztatási problémáiból indul $\mathbf{k i}, \mathrm{s}$ alapvetően arra keresi a választ, „hogy a Nemzeti Fejlesztési Tervnek Agrár és Vidékfejlesztési Operatív Programját hogyan hangoljuk össze mindenekelött a szociálpolitikával és az NFT másik négy operatív programjának a vidékfejlesztésre vonatkozó részeivel, illetve az AVOP közül mely prioritásokat részesítjük előnyben.” (244. o.) Erre a Szerző egy hat pontból álló stratégiát tart követendönek, melyet részletesen kifejt.

Mindezek kapcsán, és mindezek mellett számos kérdést vet fel a könyv, s megfogalmazza a vidékfejlesztés legfontosabb feladatait a csatlakozás tükrében. A vidék jövőjét illetően szkeptikus, helyenként pesszimista, hiszen a leginkább elmaradott vidéki térségek felzárkózására a támogatáspolitika tükrében kevés esélyt lát. Valószínüsíti, hogy az EU-csatlakozás újabb konfliktusokat okozhat a már a rendszerváltáskor is vesztes vidéki lakosság körében. Ezeknek a konfliktusoknak a csökkentése, elhárítása „komplex feladat”. Ehhez, mint fogalmaz, „,szükséges a kormány jó vidékpolitikája, a vidékkutatók problémafeltáró, elemzỏ és jövőképet felvázoló munkája, valamint az érintettek, a rurális térségben élök tenni akarása és összefogása." (248. o.)

A munkát több mint ötven ábra, s közel negyven táblázat gazdagítja, s figyelemre méltó a több száz hivatkozás, amely attól igazán értékes, hogy a vidékfejlesztés kérdéskörében megjelenő talán valamennyi vélemény megismerhetỏ általa. Az ezekből merített, az ezekkel vitázó és egyetértő gondolatok adják meg azt a szintézist, amely a szkeptikus és gondolkodó szakemberek számára ugyanúgy frissítő forrás, mint ahogy az egyetemisták számára is kiválóan használható tankönyv.

A regionális és vidékfejlesztési támogatásokhoz való sikeres hozzáférés új és nagy kihívást jelent Magyarország számára. A sikeres csatlakozáshoz pedig elengedhetetlen az Unió játékszabályainak ismerete, a sikeres vidékfejlesztési politikához pedig az uniós modell kiépítése. Többek között ehhez is segítséget nyújt Kovács Teréz könyve. 